\title{
EXAMINING THE PROFESSIONAL DEVELOPMENT PROCESSES OF PRE-SERVICE ENGLISH TEACHERS IN TURKEY
}

Burcu Ökmen ${ }^{1}$

Ministry of Education, Turkey

Abdurrahman Kılıç

Duzce University, Turkey

\begin{abstract}
The aim of this study is to reveal the development of professional knowledge and competencies among pre-service English teachers through the practice of lesson study. This study was carried out to improve pre-service teachers' teaching skills and to show the effect of the practice of lesson study. The action research method was used in this research. Each action plan is a lesson plan and each lesson plan consists of two cycles. The study group of the research consisted of two pre-service English teachers from among fourth-year students studying in the English language teaching department of a public university and taking teaching practice courses in Turkey.In the research, interview, observation, reflective daily form, student evaluation form and the letter about the process were used as data collection tool. At the end of the research, it was concluded that the lesson study method improved the knowledge and usage skills of pre-service teachers' student-centered methods and technique and positively affected the pre-service teachers' views of the teaching profession and developed their beliefs about being successful teachers.
\end{abstract}

Keywords: lesson study, professional development, pre-service English teachers, action research

Student-centered education comprises the four main elements of the student, teacher, learning environment, and learning materials, and among these elements, the teacher has an important role in designing the teaching process, increasing the effectiveness of learning materials, and organizing the learning environment (Slavin, 1994). For effective foreign language teaching, the teacher, as the practitioner of the environment, should create

1Correspondence: burcuokmen91@hotmail.com 
a suitable environment for teaching the students. Activities to be carried out with visual and audio tools in foreign language teaching will assist in the teaching and learning of the necessary words and concepts (Demirel, 1993). The most important variables affecting success in foreign language teaching are (1) the motivation of students, (2) the dominance of teachers in the field, (3) the activities performed in the class in line with teaching principles, and (4) methods and the variety of applications teachers use (Engin, 2006). In this context, the role of the teachers and teachers' professional development are important. Zepeda (2012) points out that learning to teach is a lifelong profession as it involves continuing development that is never completed.

Although Turkey gives importance to foreign language learning, in the English Proficiency Index, according to 2018 data, Turkey ranked 73rd of 88 countries and this clearly shows the shortcomings of Turkey's foreign language teaching. There are several reasons for failure to learn a foreign language. One of them can be said to be methodological problems. In Turkey, studies have investigated the problems experienced in English and other foreign language education, including the causes of failure based on the method or strategy used (Ateş \& Günbayi, 2017; Bilginer, 2010; Ökmen \& Kılıç, 2016, 2018; Solak, 2013). In addition to these studies, Suer, Demirkol, and Oral (2019) suggested that English teachers have trouble implementing the curriculum and therefore seminars or inservice training should be organized to teach English course curriculum and to encourage organizing activities.

It has been seen that in Turkey teachers are not satisfied with the professional development activities carried out in single-session seminar style and they evaluate these traditional programs as inadequate in terms of developing both their own teaching skills and the learning outcomes of students (Budak, 2012; Ozdemir, 1997; Ozdemir \& Yirci, 2015). For this reason, the lesson study model, which is a school-based professional development model (Lewis \& Tsuchida, 1998), was used in this study considering that it is effective for the professional development of pre-service teachers.

\section{Lesson Study}

Originating in Japanese elementary education and having been in use since the 1970s, lesson study is a translation of the Japanese word jugyou, which means instruction, lessons, or lesson, and kenkyuu, which means research or study (Lewis, Perry, Hurd \& O'Connell, 2006). It is an inquiry-based approach to the professional development of teacher, and it is mainly based upon teachers' collaboration, reflection, and classroom practice (Johnson, 2009). Tasker (2014) identifies lesson study as a framework used by teachers in order to find a gap between where their students are now and where they would like them to be, then look for ways that would bridge that gap by means of creating a research lesson.

Lesson study is a cyclical professional development model based on collaboration, respect for ideas, and shared production. In the lesson study model, teachers or pre-service teachers plan and apply the teaching process together to provide the most ideal and most productive outcomes for students, and the applied lesson is observed and evaluated (Takahashi \& Yoshida, 2004). According to Stigler and Hiebert (2016), the most important aim of the lesson study model is not to create perfect lessons, but rather to improve teachers' subsequent teaching. The stages of the lesson study model can be summarized as follows (Murata \& Takahashi, 2002): 
- Research Stage: This is the first stage of lesson study, where the learning outcomes, target behaviors, and problems are defined; the curriculum is comprehensively examined; and preparations are made to reach the target behaviors.

- Planning Stage: This is the stage in which a lesson plan suitable for the learning outcomes is prepared. Each stage of the course and the materials and methods or techniques to be used are planned cooperatively.

- Implementation Stage: In this stage, one of the teachers or pre-service teachers in the group implements the lesson plan. This is the data collection stage, where other teachers observe the lesson and take notes.

- Revision Meeting: In this stage, after the application of the lesson, the observations of the stakeholders who observed the lesson are shared. Here, in general, discussions are held on how to improve the implementation processes in the classroom. As a result of the observations and evaluations made, revisions are made to the plans.

Following the above stages, if desired, the revised plan is implemented in another group by another group member. The course is observed again by other group members, a meeting is held at the end of the course, and changes are made to the plan. The key concept of the cyclic design of the lesson study is to revise the lecture. Each revision meeting represents a cycle (Stigler \& Hiebert, 1999).

\section{Objectives}

The lesson study model has been implemented many times in pre-service teacher education as well as in-service training around the world (Burroughs \& Luebeck, 2010; Lamb, 2015; Zhou, Xu \& Martinovic, 2016; Angelini \& Álvarez, 2018). As a result of these implementations, it was seen that the lesson study model improved pre-service teachers' critical observation skills, made it easier for them to establish a relationship between theory and practice (Groves, 2013; Tasker, 2014), deepened their field knowledge and their knowledge about students (Groves, 2013; Hourigan \& Leavy, 2019; Zhang, Liu, Zheng, Luo \& Cheng, 2021), changed their beliefs about learning/teaching and their self-efficacy (Kanauan \& Inprasitha, 2014; Tasker, 2014; Hourigan \& Leavy, 2019), and improved their teaching analysis and feedback skills (Sims \& Walsh, 2009; Sibbald, 2009; Carrier, 2011). It involves collaborative planning, peer observation, collaborative dialogue, re-teaching and reflection in order to be able to improve teaching practice (Kotelawala, 2012).

This study examines how teacher learning is shaped by means of the social context and collaboration between colleagues, and how teacher learning leads to perceptual changes in their views of themselves as teachers. In this regard, the current study aims to shed light on the benefits of practicing lesson study and show how, if any, this practice may contribute to pre-service teachers' professional development and lead to change in their beliefs and perceptions regarding the lesson study model of professional development. In this context, in this study, it is aimed to reveal the development of the professional knowledge and competencies of pre-service English teachers through the practice of lesson study. Within the framework of this basic purpose, the study seeks to answer the following questions:

- How did pre-service teachers' skills in preparing and implementing lesson plans change during the lesson study process?

- What were the views of the pre-service teachers about preparing a lesson plan at the end of the lesson study process?

- What were the views of the pre-service teachers about their professional development at the end of the lesson study process? 
- What were the views of the pre-service teachers about their professions at the end of the lesson study process?

- What were the views of the pre-service teachers about the process at the end of the lesson study process?

- What is the effect of the lesson plans prepared in the lesson study process on students?

\section{Method}

The action research method, one of the qualitative research methods, was used in this research. In the literature, it is seen that qualitative methods are generally used in research on the lesson study model (Smith, 2008). Action research is research that helps practitioners, education managers, and teachers understand their work better (Glanz, 1999) and it entails a systematic process of intervention based on the fact that people conduct research about their professional actions and take action for change (Costello, 2007).

\section{Study Group}

The study group of the research consisted of two pre-service English teachers from among fourth-year students studying in the English language teaching department of a public university and taking teaching practice courses. Considering the purpose and method of the study, it was ensured that the pre-service teachers were willing to volunteer and to participate in all activities throughout the process. Before starting the study, pre-service teachers were told how the process would progress. It was stated that this process would be beneficial for their professional development, their lesson plan preparation and application skills would improve, and their knowledge and skills of using different methods and techniques would improve.

\section{Data collection}

Interview. The interview technique was used in this research. In the interview technique, the aim is to reveal the experiences of people and their meaning and to acquire data that answer the question of the research by examining the life story of the individuals (Kvale, 2006). In this study, interviews were held with pre-service teachers before and after the implementation. During the interviews held at the beginning of the semester, the following questions were asked: "What are the points where you feel strong and weak in preparing and implementing lesson plans? In which areas would you like to improve yourself?" At the end of the semester, the following questions were asked: "What have you experienced/felt during this process? Do you think the process has had an impact on your professional development? What has changed?"

Observation. Observation is a technique that tries to reveal the meanings of facts and events, different perspectives of the participants, and the relationships between these perspectives by performing operations such as looking and listening in a systematic way for a specific purpose (Kılıç et al., 2019). In this study, the lessons were observed by the other pre-service teacher and an English teacher, and the observation form developed by Okmen (2020) was filled out.

Reflective Diary. Reflective diaries enable the organizing of thoughts, emotions, attitudes, and hypotheses, making note of practical details about teaching and performing evaluations with relevant literature (Taylor et al., 2006). In this study, both researchers and pre-service teachers filled out reflective diaries separately. The researchers took note of the observations about the planning, revision meeting, and last meetings. The pre-service 
teachers observed the classroom environment through participant observation throughout the implementation process, and they recorded their impressions about the process regularly using the reflective diary format developed by Okmen (2020) after each lesson.

Student Evaluation Form. In order to understand the affective effects of the implementation on the students and the effects on the students' attitudes towards the lesson, volunteering students were asked to fill out the student evaluation forms developed by Dudley (2014) every week.

Letter. Pre-service teachers were asked to write a letter expressing their feelings and thoughts about the process at the end of the semester.

\section{Implementation Process}

\section{The Role of the Researchers}

Researchers have been involved in the process as an expert in all stages of the lesson study. They are lecturers in university and give 'teaching practice course'. The pre-service teachers taking 'teaching practice course' were met regularly in the process of preparing and revising the lesson plans and all plans were prepared cooperatively. In this process, researchers gave explanations for the stages in the lesson study, summarized previous discussions and/or meetings, keept track of the decisions taken by the group, and asked questions in order to guide the discussion in a way to complete each stage in the process.

\section{Preparation for Action Plans}

Preparations were made to prepare effective and efficient action plans. These are as follows:

- A literature review was performed on the subject of lesson study. What the lesson study method is, how it is applied, what stages it consists of and what needs to be considered were investigated.

- The pre-service teachers were able to make observations at the school where they would practice for 2 weeks. They observed the classroom environment, the students and the different lectures. Thus, it was ensured that they got used to the classroom environment before starting their own practices and formed some thoughts about teaching.

- Interviews were carried out with the pre-service teachers, and how they felt at the points of lesson plan preparation and implementation and the areas they thought to be strong and weak were also determined.

- The pre-service teachers were asked to examine resources such as textbooks and teaching methods and to research what the critical points of the curriculum were and how the learning outcomes should be taught. In this way, it was tried to make pre-service teachers know about the curriculum and have an opinion on different methods and techniques. It was thought that they could prepare a good lesson plan with the knowledge they gained here.

- The pre-service teachers were asked to prepare a sample lesson plan. With this, it was aimed to see the development of the pre-service teachers in the process and to determine their deficiencies in preparing a lesson plan.

According to the data obtained, the deficiencies observed in the practice school and the sample lesson plans and the concerns of the pre-service teachers were identified, as shown in Table 1. 
Table 1.

Deficiencies in Practice School and Pre-service Teachers

\begin{tabular}{|c|c|c|}
\hline Categories & $\begin{array}{l}\text { Sub- } \\
\text { categories }\end{array}$ & Codes \\
\hline \multirow{14}{*}{$\begin{array}{l}\text { Practice } \\
\text { School }\end{array}$} & Curriculum & Curriculum is not implemented \\
\hline & & $\begin{array}{l}\text { Out-of-program learning outcomes and content are processed } \\
\text { Four basic language skills are not taught }\end{array}$ \\
\hline & Method- & Grammar translation method is used \\
\hline & Technique & Question and answer technique is used \\
\hline & & Pre-solved tests are checked \\
\hline & & Worksheet is handed out and solved \\
\hline & & Test solution is done \\
\hline & & Homework is checked \\
\hline & Classroom & There is noise in class \\
\hline & management & Several students attend the lesson \\
\hline & & Students deal with the test of another lesson \\
\hline & & Students who do not bring their books cannot attend classes \\
\hline & Material & Extra book is used \\
\hline & & Only textbooks are used \\
\hline \multirow{20}{*}{$\begin{array}{l}\text { Pre-service } \\
\text { Teacher }\end{array}$} & Classroom & She's so scared she can't manage the class \\
\hline & management & She is worried about not being able to train time \\
\hline & & She thinks she will have difficulty in classroom management \\
\hline & & $\begin{array}{l}\text { She doesn't think she can take care of all students at the same } \\
\text { time }\end{array}$ \\
\hline & Method- & She doesn't want to teach grammar based lessons \\
\hline & Technique & She feels inadequate about teaching \\
\hline & & She wants to improve students' speaking skills \\
\hline & & She feels anxious about teaching listening skill \\
\hline & & $\begin{array}{l}\text { Unfortunately, the first thing that comes to mind is to teach } \\
\text { the grammar rule in a classic way. }\end{array}$ \\
\hline & Speaking & She feels nervous \\
\hline & English in & Her voice trembles \\
\hline & the course & There is a practical lack \\
\hline & & There is a lack of self-confidence \\
\hline & & Shee thinks her level is inadequate \\
\hline & Affective & She dithers \\
\hline & state & She gets very excited \\
\hline & & She is very afraid of not being a good teacher \\
\hline & & She feels nervous that students knock off her perch \\
\hline & & She gets nervous when students criticize anything \\
\hline & & $\begin{array}{l}\text { When students ask for something, she gets excited because } \\
\text { she feels inadequate }\end{array}$ \\
\hline
\end{tabular}




\begin{tabular}{|c|c|c|}
\hline Categories & $\begin{array}{l}\text { Sub- } \\
\text { categories }\end{array}$ & Codes \\
\hline & Preparing & She has difficulty in producing activities suitable for \\
\hline & lesson plan & learning outcomes \\
\hline & & She can't understand the learning outcomes and functions \\
\hline & & She does not include student-centered activities \\
\hline & & She does not use materials other than textbooks \\
\hline & & She does not pay attention to the steps of warm up, \\
\hline
\end{tabular}

In order to eliminate the problems and deficiencies seen in Table 1, attention was paid to the following points in the action plans:

- Lesson plans will be prepared in accordance with the curriculum and lessons will be taught according to the curriculum.

- Attention will be paid to the use of different student-centered methods and techniques.

- Attention will be paid to teaching four basic language skills.

- Different materials will be used.

- A lesson plan will be prepared to attract the attention of all students.

- Lesson plans will include warm up, motivation, identifying the target, and evaluation steps.

- A communicative language teaching method will be used

\section{Planning the Research Process}

The research was put into practice in the first semester of the 2019/2020 academic year. Within the scope of the research, the implementations carried out at home, at the practice school, and in the meetings are shown in Table 2 together with their dates.

Texts, examples, and videos related to the methods and techniques determined before each new plan preparation stage were sent to the pre-service teachers. In this way, they had an opportunity to learn about these methods. In addition, they were asked to examine the curriculum and learning outcomes before coming to the meetings. In the meetings, the plans were prepared cooperatively. In the final week, the pre-service teachers were asked to determine the learning outcomes and to plan and implement the plans individually in order to see their individual development in the process. In the last meeting, the latest plan and its implementation were evaluated and the participants were interviewed.

Table 2.

Implementation Process

\begin{tabular}{llll}
\hline Date & Home & Practice School & Meeting \\
\hline $21^{\text {st }}-25^{\text {th }}$ & & Observation & Interview \\
October & & \\
\cline { 2 - 4 } $28^{\text {th }}$ October - & Preparing a sample & Observation & Preparing 1 \\
$1^{\text {st }}$ November & lesson plan & & \\
\cline { 2 - 4 }
\end{tabular}




\begin{tabular}{|c|c|c|c|}
\hline Date & Home & Practice School & Meeting \\
\hline $4^{\text {th }}-8^{\text {th }}$ & & Implementing $1^{\text {st }}$ & Revising $1^{\text {st }}$ lesson plan \\
\hline November & & lesson plan & \\
\hline $\begin{array}{l}11^{\text {th }}-15^{\text {th }} \\
\text { November }\end{array}$ & $\begin{array}{l}\text { Working on } \\
\text { determined methods } \\
\text { and techniques, } \\
\text { determining learning } \\
\text { outcomes }\end{array}$ & $\begin{array}{l}\text { Implementing } 1^{\text {st }} \\
\text { revised lesson plan }\end{array}$ & $\begin{array}{l}\text { Deciding the final form } \\
\text { of } 1^{\text {st }} \text { lesson plan- } \\
\text { Preparing } 2^{\text {nd }} \text { lesson plan }\end{array}$ \\
\hline $\begin{array}{l}18^{\text {th }}-22^{\text {nd }} \\
\text { November }\end{array}$ & Semester break & & \\
\hline $\begin{array}{l}25^{\text {th }}-29^{\text {th }} \\
\text { November }\end{array}$ & & $\begin{array}{l}\text { Implementing } 2^{\text {nd }} \\
\text { lesson plan }\end{array}$ & Revising $2^{\text {nd }}$ lesson plan \\
\hline $\begin{array}{l}2^{\text {nd }}-6^{\text {th }} \\
\text { December }\end{array}$ & $\begin{array}{l}\text { Working on } \\
\text { determined methods } \\
\text { and techniques, } \\
\text { determining learning } \\
\text { outcomes }\end{array}$ & $\begin{array}{l}\text { Implementing } 2^{\text {nd }} \\
\text { revised lesson plan }\end{array}$ & $\begin{array}{l}\text { Deciding the final form } \\
\text { of } 2^{\text {nd }} \text { lesson plan- } \\
\text { Preparing } 3^{\text {rd }} \text { lesson plan }\end{array}$ \\
\hline $\begin{array}{l}9^{\text {th }}-13^{\text {th }} \\
\text { December }\end{array}$ & & $\begin{array}{l}\text { Implementing } 3^{\text {rd }} \\
\text { lesson plan }\end{array}$ & Revising $3^{\text {rd }}$ lesson plan \\
\hline $\begin{array}{l}16^{\text {th }}-20^{\text {th }} \\
\text { December }\end{array}$ & $\begin{array}{l}\text { Working on } \\
\text { determined methods } \\
\text { and techniques, } \\
\text { determining learning } \\
\text { outcomes }\end{array}$ & $\begin{array}{l}\text { Implementing } 3^{\text {rd }} \\
\text { revised lesson plan }\end{array}$ & $\begin{array}{l}\text { Deciding the final form } \\
\text { of } 3^{\text {rd }} \text { lesson plan- } \\
\text { Preparing } 4^{\text {th }} \text { lesson plan }\end{array}$ \\
\hline $\begin{array}{l}23^{\text {rd }}-27^{\text {th }} \\
\text { December }\end{array}$ & & $\begin{array}{l}\text { Implementing } 4^{\text {th }} \\
\text { lesson plan }\end{array}$ & Revising $4^{\text {th }}$ lesson plan \\
\hline $\begin{array}{l}30^{\text {th }} \\
\text { December- } 3^{\text {rd }} \\
\text { January }\end{array}$ & & $\begin{array}{l}\text { Implementing } 4^{\text {th }} \\
\text { revised lesson plan }\end{array}$ & $\begin{array}{l}\text { Deciding the final form } \\
\text { of } 4^{\text {th }} \text { lesson plan- } \\
\text { Interview }\end{array}$ \\
\hline $\begin{array}{l}6^{\text {th }}-10^{\text {th }} \\
\text { January }\end{array}$ & $\begin{array}{l}\text { Preparing an } \\
\text { individual plan }\end{array}$ & $\begin{array}{l}\text { Implementing the } \\
\text { plan }\end{array}$ & Evaluation of semester \\
\hline
\end{tabular}

\section{Lesson Cycles}

Action plans are prepared in two cycles. Accordingly, each lesson plan represents action research and two cycles. The cycles of the lesson plans implemented by the preservice teachers throughout the semester are shown in Table 3.

Lesson study includes processes designed for at least 5 weeks in Japan (Murata \& Takahashi, 2002). This study includes a 2-cycle and 9-week period. As can be seen in Table 3 , two different plans were prepared each week and implemented by two different preservice teachers in different classes. Each plan was prepared to be implemented in 2 lesson hours. Each lesson was observed by the other pre-service teacher and 1 English teacher, and notes were taken for the course process. The pre-service teacher who implemented the 
lesson plan also completed a reflective diary entry at the end of the lesson and explained her feelings and thoughts about the process. At the end of the lesson, student evaluation forms were distributed to volunteering students to evaluate the course process.

Table 3.

Plan of Lesson Cycles

\begin{tabular}{|c|c|c|c|c|}
\hline Week & Elif & Class & Selin & Class \\
\hline \multicolumn{5}{|c|}{$1^{\text {st }}$ Plan } \\
\hline $1^{\text {st }}$ Week & Plan 1a & $12 \mathrm{~A}$ & Plan 1b & $12 \mathrm{~B}$ \\
\hline
\end{tabular}

\section{Revision}

$2^{\text {nd }}$ Week

Plan $1 b$

$12 \mathrm{~A}$

Plan 1a

$12 \mathrm{~B}$

Deciding the final form of Plan1 $a$ and Plan1b

\begin{tabular}{|c|c|c|c|c|}
\hline \multicolumn{5}{|c|}{$\underline{2^{n d} \text { Plan }}$} \\
\hline $3^{\text {rd }}$ Week & Plan2a & $12 \mathrm{~B}$ & Plan2b & $12 \mathrm{~A}$ \\
\hline \multicolumn{5}{|c|}{ Revision } \\
\hline $4^{\text {th }}$ Week & Planeb & $12 \mathrm{~B}$ & Plan2a & $12 \mathrm{~A}$ \\
\hline \multicolumn{5}{|c|}{ Deciding the final form of Plan2a and Plan2b } \\
\hline \multicolumn{5}{|c|}{$\underline{3^{r d} \text { Plan }}$} \\
\hline $5^{\text {th }}$ Week & Plan3a & $12 \mathrm{~A}$ & Plan3b & $12 \mathrm{~B}$ \\
\hline \multicolumn{5}{|c|}{ Revision } \\
\hline $6^{\text {th }}$ Week & Plan3b & $12 \mathrm{~A}$ & Plan3a & $12 \mathrm{~B}$ \\
\hline \multicolumn{5}{|c|}{ Deciding the final form of Plan3a and Plan3b } \\
\hline \multicolumn{5}{|c|}{$4^{\text {th }}$ Plan } \\
\hline $7^{\text {th }}$ Week & Plan4a & $12 \mathrm{~B}$ & Plan4b & $12 \mathrm{~A}$ \\
\hline \multicolumn{5}{|c|}{ Revision } \\
\hline $8^{\text {th }}$ Week & Plan $4 b$ & $12 \mathrm{~B}$ & Plan4a & $12 \mathrm{~A}$ \\
\hline \multicolumn{5}{|c|}{ Deciding the final form of Plan4a and Plan $4 b$} \\
\hline \multicolumn{5}{|c|}{$\underline{5^{\text {th }} \text { Plan }}$} \\
\hline $9^{\text {th }}$ Week & Plan5a & $12 \mathrm{~A}$ & Plan5b & $12 \mathrm{~B}$ \\
\hline
\end{tabular}

In revision meetings, the reflective diaries, observation forms, and student evaluation forms were examined, and the pre-service teachers shared their observations and thoughts. The necessary regulations were reflected in the revised plans in consensus.

The revised plan was implemented by a different teacher in a different class. Following the implementation of the revised plan, reflective diaries, observation forms, and student evaluation forms were examined again, and the pre-service teachers shared their observations and thoughts and the final plan was decided. Before each new plan was 
prepared, changes made to previous plans, problems experienced, and solutions were taken into consideration.

The plans were prepared to use different teaching methods and techniques every week. The methods and techniques used in the plans are shown in Table 4.

Table 4.

Methods and Techniques Used in Plans

\begin{tabular}{ll}
\hline Plans & Methods and Techniques \\
\hline Plan1a- Plan1b & Working groups-discussion \\
Plan2a- Plan2b & Bearing-station-educational game-song \\
Plan3a- Plan3b & Educational game-role play \\
Plan4a- Plan4b & Researching - preparing presentations - card matching - \\
& snowball \\
Plan5a-Plan5b & Station, role play- debate-educational game \\
\hline
\end{tabular}

First Action Plan

Planning Process. According to the data obtained from the student evaluation forms, reflective diaries and teacher observation forms, what happened in the process of planning the first action plan is as follows:

- They had difficulties in understanding the learning outcomes in the process of plan preparation.

- They had difficulties in producing activities suitable for learning outcomes.

- They had difficulties in producing materials.

- They understood the lesson plan's warm up, motivation, and informing the target. They included these stages in the plan.

Revision Meeting. As a result of the implementation of Plan 1a and Plan 1b, it was decided to make the following changes in the lesson plans according to the data obtained from student evaluation forms, reflective diaries, and teacher observation forms:

- It was decided to pay attention to the implementation of the warm up, motivation, and evaluation stages.

- For the reading activity to be successful:

$\checkmark$ The order of the activities was changed.

$\checkmark$ It was decided to give a word list.

$\checkmark \quad$ It was decided to give the opportunity to work individually.

$\checkmark$ It was decided to first of all ask the students to identify basic words that they did not know/could not guess/were new to them.

$\checkmark$ After the students finished the activity, it was decided to ask them questions.

- In order to increase student participation:

$\checkmark$ The number of spokespeople was increased in the discussion.

$\checkmark$ The groups were asked to answer each other.

$\checkmark$ It was decided to give the opportunity to work individually.

$\checkmark$ It was decided to increase the number of examples given to human rights.

\section{Second Action Plan}

Planning Process. According to the data obtained from the student evaluation forms, reflective diaries and teacher observation forms, what happened in the process of planning 
the second action plan is as follows:

- Attention was paid to timing in the plans. Time period of each activity was determined.

- In lesson plans, it was stated that how long each activity will last

- They had difficulty in preparing the step of warm up.

- They had difficulty in reconciling the activities with the learning outcomes.

- They had difficulties in understanding and associating learning outcomes and functions in curriculum.

- They had difficulties in associating the reading texts in the book with the theme and learning outcomes in curriculum.

- They couldn't understand the importance of group work. So they tried to prepare individual activities. However, since there was a positive feedback about the group work in Plan 1a and Plan1b, group work was included in the plans.

- They had difficulty in planning the lesson so that all students could participate in the lesson.

- They had difficulty in preparing the material.

Revision Meeting. As a result of the implementation of Plan 2a and Plan 2b, it was decided to make the following changes in the lesson plans according to the data obtained from student evaluation forms, reflective diaries, and teacher observation forms:

- The delivery technique was adjusted for students to be sitting, not standing.

- It was decided to turn the stations around in the classroom.

- It was decided to change the video used in the warm up stage of the lesson plan.

- It was decided to deal with students who disrupt the teacher and other students outside of class and to ensure the students' participation in the lesson.

\section{Third Action Plan}

Planning Process. According to the data obtained from student evaluation forms, reflective diaries and teacher observation forms, what happened in the process of planning the third action plan is as follows:

- They had difficulty in warm up stage of lesson plan.

- Timing was made in detail in the plans.

- Instructions on how to create groups and what to do were explained in detail.

- They did not have difficulty in preparing the material.

- They were more successful at adapting activities to the learning outcomes.

Revision Meeting. As a result of the implementation of Plan 3a and Plan 3b, it was decided to make the following changes in the lesson plans according to the data obtained from student evaluation forms, reflective diaries, and teacher observation forms:

- It was decided to explain the instructions in the game activity more clearly and understandably.

- It was decided to deal with the students who do not want to participate in the lesson outside of class and to ensure students' participation in the lesson.

\section{Fourth Action Plan}

Planning Process. According to the data obtained from the student evaluation forms, reflective diaries and teacher observation forms, what happened in the process of planning 
the fourth action plan is as follows:

- They did not have difficulty in preparing the warm up stage of lesson plan.

- Timing was made in detail in the plans.

- They tried to write the instructions in detail.

- They did not have difficulty in producing materials.

- They was more successful at adapting activities to the learning outcomes.

Revision Meeting. As a result of the implementation of Plan 4a and Plan 4b, it was decided to implement the plans without changing them again as there were now no negative views of the plans. Negative views were not reported about the re-implemented plans and the positive views were similar to the views stated in the first implementation. For this reason, it was decided not to change the plans.

\section{Data Analysis}

To analyze the data, the content analysis method was used. Content analysis allows the data to be gathered in the framework of certain notions and themes and transforms them into a format that readers can understand easily (Fraenkel \& Wallen, 2000). The data analysis process was carried out in three stages (Kılıç et al., 2019): organizing data, summarizing data, and associating/interpreting. The data were combined and grouped and made ready for analysis at the stage of organizing data. The forms were coded to express each participant. These codes were also used in direct quotes. During the stage of summarizing data, coding and classification processes were carried out. Meaningful elements on the data were encoded and these codes were collected under categories and subcategories. The categories that emerged were interpreted by associating them with each other at the stage of association/interpretation. As a result 10 themes emerged. These are as follows: "Views About Process", "Views About Teaching Profession", "Views About Professional Development", "Views About Preparing a Lesson Plan", "Views About the Implementation Process of Individual Plans", "Problems in the Implementation Process", "Problems in the Implementation Process of Revised Plans", "Problems in the Implementation Process", "Problems in the Implementation Process of Revised Plans", and "Problems in the Implementation Process".

In addition, in order to ensure confidentiality in the presentation of the data, the pseudonyms "Elif" and "Selin" were given to the pre-service teachers. Quotations from the pre-service teachers' and students' statements are provided using their original expressions.

\section{Validity and Reliability}

Data diversification has been done to make the research reliable. Interviews, student evaluation forms, process letters, reflective diaries, and observation forms were used as data collection tools. Data collected within the scope of the research were coded twice with the code/re-code strategy. This strategy requires the researcher to encode the same data twice with at least one or two weeks of waiting time between each encoding. The two encoding results are compared to see if the results are the same or different (Anney, 2014). Within the scope of this research, the focus group interview was re-coded by the researcher and consistency was calculated using the reliability formula proposed by Miles and Huberman (1994): Reliability = Consensus / (Consensus + Disagreement). The agreement between the codings was found to be $95 \%$ for the interviews, $96 \%$ for student evaluation forms, $92 \%$ for process letters, $92 \%$ for reflective diaries, and $91 \%$ for observation forms. Studies with a 
coefficient of agreement above 70\% are considered reliable (Miles \& Huberman, 1994). These results show that the research is reliable.

\section{Results and Findings}

All findings were presented under themes. Themes were explained in detail with categories and codes. Codes are the original and most meaningful element in the data. Category is the name given to the meaningful code group formed by similar codes. Theme, on the other hand, consists of interrelated categories combined under a heading.

\section{First Action Plan Process}

Problems in the first action plan were examined in terms of the implementation process and the implementation process of the revised plan.

Implementation Process. According to the results of the analysis of the data obtained from student evaluation forms, reflective diaries, and teacher observation forms, the problems in the implementation process of Plan 1a and Plan $1 \mathrm{~b}$ are presented according to the relevant themes in Table 5 .

\section{Table 5.}

Problems in the Implementation Process

\begin{tabular}{ll}
\hline Categories & Codes \\
\hline Lesson plan & $\begin{array}{l}\text { Summarization wasn't made at the end of the course } \\
\text { Warm up and motivation stages of plan were implemented }\end{array}$ \\
$\begin{array}{l}\text { Classroom } \\
\text { management }\end{array}$ & $\begin{array}{l}\text { There was noise in class } \\
\text { Activites ended early } \\
\text { She couldn't use tone well } \\
\text { She had difficulties in classroom management } \\
\text { There were students who did not attend the lesson } \\
\text { process }\end{array}$ \\
& $\begin{array}{l}\text { She used English less } \\
\text { Texts were not understood } \\
\end{array}$ \\
& $\begin{array}{l}\text { She couldn't tell instruction well } \\
\text { She did not correct student's mistakes } \\
\text { There were students who wanted to do individual activities }\end{array}$ \\
\end{tabular}

As seen in Table 5, all stages of Plan 1a and Plan 1b were not implemented by the pre-service teachers. They stated that they had difficulties in classroom management. Elif described what she experienced in the lesson process as follows: "I think the biggest problem in the class was noise. There was a lot of noise. Also, some students did not want to join groups." One of the students expressed his opinion on this issue as follows: "I do not want to do anything with the group. I would be glad for something different next time."

It was also observed that the pre-service teachers did not correct students' mistakes, they gave incomplete instructions, and activities ended earlier than planned. Regarding this issue, Selin explained: "Activities were over but I saw that there was more time until break time. I was worried for a moment. I thought 'What will I do?' Then I added something off the top of my head. I was stressed at that moment."

Implementation Process of Revised Plan. According to the results of the analysis of the data obtained from student evaluation forms, reflective diaries, and teacher observation 
forms, the problems in the implementation process of revised Plan 1a and Plan 1b are presented according to the relevant themes in Table 6.

Table 6.

Problems in the Implementation Process of Revised Plans

Categories Codes

Lesson She couldn't tell instruction well

process She did not correct student's mistakes

She did not establish discretion / praise sentences for students

Classroom She couldn't use time efficiently

management Large groups caused noise in the classroom

As seen in Table 6, the problems in the revised plans were decreased. Accordingly, as a result of the changes made in the revision meeting, it can be said that the revised lesson plan was implemented more successfully. However, it was observed that some problems were still experienced due to both the lesson plan itself and the practices of the pre-service teachers. Accordingly, in the last meeting, it was decided to form small groups in Plan 1a and Plan $1 \mathrm{~b}$ and to determine the time period of each activity, and the final versions of the plans were prepared.

\section{Second Action Plan Process}

Problems in the second action plan were examined in terms of the implementation process and the implementation process of the revised plan.

Implementation Process. According to the results of the analysis of the data obtained from student evaluation forms, reflective diaries, and teacher observation forms, the problems in the implementation process of Plan $2 \mathrm{a}$ and Plan $2 \mathrm{~b}$ are presented according to the relevant themes in Table 7 .

\section{Table 7.}

Problems in the Implementation Process

\begin{tabular}{|c|c|}
\hline Categories & Codes \\
\hline Lesson plan & $\begin{array}{l}\text { Video used in warmn up stage was not good quality } \\
\text { Teacher struggled to attract student attention }\end{array}$ \\
\hline $\begin{array}{l}\text { Classroom } \\
\text { management }\end{array}$ & $\begin{array}{l}\text { There was too much noise because of activities } \\
\text { There were students, who disrupted teacher and other students }\end{array}$ \\
\hline $\begin{array}{l}\text { Lesson } \\
\text { process }\end{array}$ & $\begin{array}{l}\text { She used English less } \\
\text { She had difficulty in grouping } \\
\text { She did not correct student's mistakes } \\
\text { There was chaos as the groups moved }\end{array}$ \\
\hline
\end{tabular}

As seen in Table 7, there were problems in the warm up stages of the plans, in ensuring the participation of all students, and in organizing the activities. Elif expressed what she experienced during the lesson as follows: "The classroom was suddenly confused while doing the activity. I didn't know what to do. I was stressed when trying to manage the groups, and to be honest, I didn't even think to speak English at that time." 
Implementation Process of Revised Plan. According to the results of the analysis of the data obtained from student evaluation forms, reflective diaries, and teacher observation forms, the problems in the implementation process of revised Plan 2a and Plan $2 \mathrm{~b}$ are presented according to the relevant themes in Table 8.

Table 8.

Problems in the Implementation Process of Revised Plans

\begin{tabular}{ll}
\hline Categories & Codes \\
\hline Lesson plan & She had difficulty in motivating students \\
$\begin{array}{ll}\text { Classroom } \\
\text { management }\end{array}$ & $\begin{array}{l}\text { Chaos occurred as the class is crowded in the bearing activity } \\
\text { There was a problem during the displacement of the groups at the } \\
\text { station activity as the instructions were explained incomplete }\end{array}$ \\
\hline
\end{tabular}

As seen in Table 8, problems in the revised plans had decreased. Accordingly, as a result of the changes made in the revision meeting, it can be said that the revised lesson plan was implemented more successfully. The problems experienced in the revised plans were taken into consideration, small changes were made in the motivation stage of the plans, and the directions for delivery and station activities were more clearly stated in the plans when deciding their final versions.

\section{Third Action Plan Process}

Problems in the third action plan were examined in terms of the implementation process and the implementation process of the revised plan.

Implementation Process. According to the results of the analysis of the data obtained from student evaluation forms, reflective diaries, and teacher observation forms, the problems in the implementation process of Plan $3 \mathrm{a}$ and Plan $3 \mathrm{~b}$ are presented according to the relevant themes in Table 9.

\section{Table 9.}

Problems in the Implementation Process

\section{Codes}

Students are reluctant to engage in dialogue

The students did not make a sentence because of the missing instructions in the game.

As seen in Table 9, there were not many problems in the implementation process of Plan 3a and Plan 3b. No negativity was expressed other than regarding missing instructions and reluctant students.

Implementation Process of Revised Plan. According to the results of the analysis of the data obtained from student evaluation forms, reflective diaries, and teacher observation forms, it was observed that no problems in the implementation process of the revised Plan $3 \mathrm{a}$ and Plan $3 \mathrm{~b}$ were reported. For this reason, the plans were not changed.

\section{Fourth Action Plan Process}

According to the results of the analysis of the data obtained from student evaluation forms, reflective diaries, and teacher observation forms, no problems were reported in the implementation process of Plan $4 \mathrm{a}$ and Plan $4 \mathrm{~b}$. For this reason, it was decided not to change the plans. 


\section{Views About the Individual Lesson Plans}

When the plans prepared by pre-service teachers at the end of the semester were examined, the following points came to the fore:

- It was seen that the steps of warm up, motivation, identifying the target, and evaluation that should be in a lesson plan were explained in detail.

- Student-centered activities were included.

- Group work was included.

- Timing was considered in detail in the plans and the stages of the activities were planned by determining their durations.

- All instructions were explained in detail.

- Activities suitable for the planned acquisitions were selected.

- The learning outcome and function relationship specified in the curriculum was established.

According to the results of the analysis of the data obtained from student evaluation forms, reflective diaries, and teacher observation forms, the views about the implementation process of individual plans are presented according to the relevant themes in Table 10.

Table 10.

Views About the Implementation Process of Individual Plans

\begin{tabular}{|c|c|c|}
\hline Categories & $\begin{array}{l}\text { Sub- } \\
\text { Categories }\end{array}$ & Codes \\
\hline \multirow{15}{*}{ Teacher } & Lesson plan & She reminded pre-learning \\
\hline & & She told instructions well \\
\hline & & She summarized the lesson \\
\hline & & She implemented all stages of plan \\
\hline & & She attracted the students' attention \\
\hline & & She made appropriate entrance to the lesson \\
\hline & & She used material appropriate for student level \\
\hline & Classroom & She used time well \\
\hline & management & Student participation was high \\
\hline & & She took care of students to ensure student \\
\hline & & She used her voice and body language effectively \\
\hline & Lesson & Class interaction was high \\
\hline & process & She corrected student's mistakes \\
\hline & & She manages activities effectively \\
\hline & & She established discretion / praise sentences for students \\
\hline \multirow{10}{*}{ Student } & General & Games were fun \\
\hline & opinion & Time passed quickly in the lesson \\
\hline & & It was nice to have an applied lesson \\
\hline & & English can be learned if this is the case \\
\hline & Advantages & He learned new words \\
\hline & & He thinks he can love English \\
\hline & & He learned new sentence patterns \\
\hline & & He learned the word pronunciation \\
\hline & & He realized that he could speak better \\
\hline & & He feels that he is developing by making a dialogue \\
\hline
\end{tabular}


As seen in Table 10, problems with preparing an effective plan, implementing the plan, timing, classroom management, ensuring participation in the lesson, or explaining the instructions fully did not occur at the end of the process. This shows that the pre-service teachers' skills in preparing a lesson plan and implementing it were effectively developed.

\section{Pre-service Teachers' Views About the Process}

According to the results of the interviews and the analysis of the letters, the preservice teachers' views were examined in terms of their views about preparing a lesson plan, views about professional development, views about the profession of teaching, and views about the process.

Views About Preparing a Lesson Plan. The views of the pre-service teachers about preparing lesson plans are presented in Table 11 according to the relevant themes.

\section{Table 11.}

Views About Preparing a Lesson Plan

\begin{tabular}{|c|c|}
\hline Categories & Codes \\
\hline Preparation & $\begin{array}{l}\text { It took a week to prepare her first plan } \\
\text { She had a hard time with her first lesson plan } \\
\text { She was able to prepare the final plan very quickly } \\
\text { Now she can instantly change the plan according to the situation of the } \\
\text { class }\end{array}$ \\
\hline Importance & $\begin{array}{l}\text { She understood that the lesson plan was a teacher's must } \\
\text { She realized that the most important thing was the lesson plan }\end{array}$ \\
\hline $\begin{array}{l}\text { Affective } \\
\text { state }\end{array}$ & $\begin{array}{l}\text { Lesson plan increased their self-confidence } \\
\text { She felt very comfortable when she had a lesson plan } \\
\text { She doesn't worry when the lesson plan is available } \\
\text { She gets nervous when she is in class without a lesson plan }\end{array}$ \\
\hline Advantage & $\begin{array}{l}\text { The lesson is more efficient } \\
\text { There is no problem with time } \\
\text { She doesn't forget what she will teach } \\
\text { It makes classroom management easier } \\
\text { She learned how to carry out the stages of the lesson } \\
\text { It is difficult to determine what and when to do without a lesson plan } \\
\text { Lessons end quickly because she doesn't know what to do without a } \\
\text { lesson plan }\end{array}$ \\
\hline $\begin{array}{l}\text { Preparation } \\
\text { of lesson } \\
\text { plan } \\
\text { together }\end{array}$ & $\begin{array}{l}\text { It lets you create new activities } \\
\text { It allows you to complete your deficiencies }\end{array}$ \\
\hline $\begin{array}{l}\text { Revision of } \\
\text { the plans }\end{array}$ & $\begin{array}{l}\text { Lessons are getting better } \\
\text { It is an opportunity to improve the lesson plan }\end{array}$ \\
\hline
\end{tabular}


As seen in Table 11, the views of pre-service teachers about preparing lesson plans consist of the themes of "preparation", "importance", "affective status", "advantage", "preparing a lesson plan", and "revising the plans".

The pre-service teachers stated that they had difficulty in preparing lesson plans at the beginning of the semester, but they could prepare plans more easily at the end of the semester. Selin explained her change in this process as follows: "When you say 'first plan', I remember we looked at each other for hours. We could not decide what to do and how. But now it's so easy. I immediately look at my learning outcome and prepare it quickly."

They stated that they understood the importance of the lesson plan and their uneasy feelings in the classroom without it, and that the time was more productive thanks to the lesson plan and it made classroom management easier. Elif expressed her views on this issue as follows: "When you prepare a good plan, you feel more comfortable in the classroom. I saw it. When you have a plan, you are confident. There is no problem with time."

It was stated that the preparation of lesson plans makes it possible to produce new activities and also makes it easier to address deficiencies. It was also stated that revising the plans improved the lessons and plans.

Views About Professional Development. The views of the pre-service teachers about professional development are presented in Table 12 according to the relevant themes.

Table 12.

Views About Professional Development

\begin{tabular}{ll}
\hline Categories & Codes \\
\hline Classroom & She learned to control the class \\
management & She had no difficulty in classroom management \\
& She saw that activities make classroom management easier \\
& She realized that noise in the classroom was part of teaching \\
& When there is an unexpected situation in the classroom, she can \\
& immediately develop a solution
\end{tabular}

Preparing an She learned to produce new activities

activity She learned to practice different activities

She can predict how long which activity will last

She understood the importance of lecturing with activities

She saw that all students could attend the lesson thanks to the activities

She understood thats she could teach every subject with every activity

When she lectured with the activities, she realized that she was not tired in the lesson.

She can change an activitiy and implement it for different learning outcomes

Learning She learned where and what to do

outcome She learned how learning outcomes can be taught

She can easily combine learning outcomes and activities

Now she can select/design the most effective activity for the learning outcome 
As seen in Table 12, the views of the pre-service teachers about professional development consist of the themes of "classroom management", "preparing an activity", and "teaching the learning outcome".

The pre-service teachers stated that they learned classroom management, became able to produce solutions in unexpected situations, and saw that lecturing with activities made classroom management easier. Anxious about classroom management at the beginning of the semester, Selin expressed her views at the end as follows: "I was most afraid of classroom management. I was thinking I couldn't, I couldn't manage. But in this process, I saw that if you are ready, if you are certain, you will not have a problem. Noise in the classroom was not always a problem. The children were learning while they were active."

In this process, the pre-service teachers stated how important it is to teach lessons with different activities, as this increases student participation and facilitates learning. It was stated that this process improved their skills in preparing and implementing different activities. Selin expressed her views on this subject as follows: "Actually, when you said at first 'Lessons should be planned according to student-centered activities', I did not think that this could happen. But now I understand how important it is. As such, you are not tired and students are really learning."

The pre-service teachers stated that they learned what should be done to teach a learning outcome in this process and that they no longer had difficulties in combining learning outcomes and activities, and they could easily produce an activity suitable for the learning outcome. Elif expressed her views on this issue as follows: "God, at first, I could not find an activity suitable for the learning outcome, or I could not make the activity suitable for the learning outcome. I thought for hours. But now it is very good. I take a look at the learning outcome and I can think of something or I can produce something right away."

Views About Teaching Profession. The views of the pre-service teachers about the teaching profession are presented in Table 13.

\section{Table 13.}

Views About Teaching Profession

\section{Codes}

Now she wants to be appointed as soon as possible

Fortunately she thinks she chose this profession

She had prejudice against teaching before

The perspective of teaching and students has changed

In fact, she understood how difficult teaching was

Previously she thought teaching was easy

She understood how right she did by choosing teaching

She believes that if she teaches in this way, she will be a successful teacher.

She saw that teaching is not just a profession but a heart job

As seen in Table 13, the pre-service teachers' attitudes towards the teaching profession had changed at the end of this process. They stated that their prejudices about teaching had changed; it was not an easy profession, but they were happy that they had chosen it. Elif expressed her views on this issue as follows: "I thought [teaching] was very easy at first. I mean, what could it be? ... you will explain it and it will be over. But it was never like that. The issue was before the lesson. You are preparing a lot. Then those students are waiting for you. You have to do something good, be a good teacher." Selin expressed her thoughts on the 
same subject as follows: "I'm glad I'm here. I trust myself more now. If this happens, you can be a good teacher."

Views About Process. The views of the pre-service teachers about the process are presented in Table 14.

As seen in Table 14, the views of the pre-service teachers about the process consist of the themes of "affective state", "advantage", and "observation".

The pre-service teachers stated that they experienced feelings they had never felt before, that they were very happy in the classroom, and that their beliefs about themselves improved. Selin expressed her thoughts on this issue as follows: "I was very afraid of class management. But I never regretted it. It was unique to be with students. I wanted it to never end." Elif expressed her thoughts on the same subject as follows: "I was really upset with the last lesson - I wished it didn't end. In this process, my belief in being a teacher has really increased."

Table 14.

Views About Process

\begin{tabular}{ll}
\hline Categories & Codes \\
\hline Affective state & Her self-confidence increased \\
& She never regretted being in class \\
& She is sad because semester is over \\
& She felt the emotions she never felt \\
Being with students is a unique feeling & She is happy when she enters the classroom \\
& Being in class, teaching something makes her happy \\
& She thinks she improved \\
& Her creativity improved \\
& She improved on student-teacher relationship \\
& She believes this semester is full of experience \\
& She learned a lot about lecturing and preparing activities \\
& She believes she can no longer teach lessons in different way \\
& She definitely thinks she is no longer the person like at the beginning of \\
the semester & \\
& She thinks it is very useful \\
Mistakes are not repeated again \\
She learned to adjust the tone \\
She learned to motivate the student \\
When lesson is observed, plans can be revised better \\
The observer can better see the deficiencies in the lesson \\
She learned that she should give positive feedback to the student \\
When lesson is observed, activities are improving more and more \\
When you observed, you can better recognize your own deficiencies \\
She understood that the student should be appreciated in all circumstances \\
\hline
\end{tabular}

The pre-service teachers stated that this process was valuable for them, they were definitely different compared to the beginning of the period, they learned a lot about lecturing and preparing activities, and their creativity improved. Elif expressed her thoughts on this subject as follows: "I learned so much this semester. I really developed 
professionally. This semester was full of experiences. I now know how a lesson can be taught effectively and what to do. I saw this semester how communicating with students should be done, how to react."

The pre-service teachers stated that it is beneficial to observe in lessons, provide the opportunity to revise the next lesson more effectively, and be helped to realize one's own mistakes better. Selin expressed her thoughts on this subject as follows: "You sometimes don't realize everything during the lesson. An outsider understands more clearly. For you, for example, everything is very good. But then we come together, for example, and she says that you didn't realize something, something happened in this activity, and then you understand, yes, that's true. This time you can change yourself or the plan."

\section{Discussion and Conclusion}

In this study, which examines the development of the professional knowledge and competencies of pre-service English teachers with the implementation of lesson study, the following results were reached according to the research findings. Results were presented in the scope of research objectives.

\section{The Pre-Service Teachers'Skills in Preparing and Implementing Lesson Plans}

First, it was concluded that the pre-service teachers, who had difficulties in understanding the learning outcomes and functions stated in the English curriculum and the structure of the curriculum at the beginning of the semester, could better understand the learning outcomes and the structure of the curriculum and develop a suitable lesson plan at the end of the semester. In this case, it can be said that the pre-service teachers' curriculum literacy improved. Ayantas (2019) reached similar results while working with pre-service social studies teachers. Cerbin and Kopp (2006) also stated that the lesson study method improved teachers' comprehension of learning outcomes and teaching practices. Lesson study model situates teacher learning in real classroom practice, and in this way helps teachers relate what they have learnt to what they do in the classroom and raise teachers' awareness towards different ways for putting their knowledge into practice (Loughran, 2002).

Thanks to lesson study, it was seen that the lesson plans prepared with the group improved the skills of the teachers to prepare and implement lesson plans suitable for the curriculum. As a result of the research conducted by Groves (2013), it was concluded that the teachers gave importance to the planning, implementation, and evaluation stages of their lessons and they were successful in group studies. Fernandez (2010) stated that with the support of a supervisor, situations such as making lesson plans as a group, analyzing, thinking about what to do, and exchanging information based on collaborative studies had a positive effect on pre-service mathematics teachers' teaching knowledge. Baki and Arslan (2015), on the other hand, stated that they reached the conclusion that the lesson study group experienced positive development in considering the planning of lessons and performed better than the pre-service teachers of the other group in terms of arranging the number of activities, completing the learning/teaching process with a learning outcome, and putting activities into order.

\section{The Views of Pre-Service Teachers About Their Professional Development and Professions}

It was seen that the lesson study method improved pre-service teachers' studentcentered methods and technique usage skills. Ayantas (2019) reported similar results in a 
study conducted with pre-service social studies teachers. Also, as a result of the study carried out by Karabug (2018), it was found that the lesson study method led to improvements in teachers' classroom practices and perspectives. Yoshida and Jackson (2011) and Murata and Pothen (2011) also found that the lesson study method developed teachers' knowledge of teaching in the field and offered the chance to combine their teaching experience in the field with theoretical knowledge by giving pre-service teachers a chance to use different teaching activities. According to Yoshida (2012) spending more time studying content and curriculum, developing a strong pedagogical content knowledge with colleagues, and establishing a professional community of learning through lesson study help it to be effective for improving classroom teaching and learning. Hourigan and Leavy (2019) also stated that as a result of engaging in lesson study, participants report an increased awareness of the importance of deep content knowledge in addition to adopting a learner-centred approach to their practice.

It was concluded that lesson study improved pre-service teachers' class and time management skills. According to Puncher and Taylor (2006) in the process of lesson study teachers' planning and work can have an impact on student engagement in the classroom in a way that they had not realized. Ayantas (2019) reported similar conclusions from his work with pre-service social studies teachers. Pektas (2014) also stated that the lesson study method improved pre-service teachers' class and time management knowledge and skills. In this study it can be said that preparing a lesson plan facilitates classroom and time management.

It was seen that lesson study positively affected the pre-service teachers' views of the teaching profession and developed their beliefs about being successful teachers. As a result of the implementation of the lesson study method with pre-service English teachers, Karabug (2018) also stated that this method benefited teachers in terms of personal and professional development. Hurd and Licciardo-Mosso (2005) stated that lesson study esteemed teachers as professionals and paved the way for them to use skills and experiences in a way that would increase student achievement while increasing their knowledge as professionals as well.

\section{The Views of the Pre-Service Teachers About the Process}

It was seen that observing the lessons within the scope of lesson study improved the lessons and enabled the teachers to improve themselves. Cerbin and Kopp (2006) stated that the observations made in lesson study provided practical data to improve the lessons. Kukey (2018) also stated that the observations enabled the deficiencies in the lesson to be noticed and corrected; as a result, different techniques could be implemented. Lesson study makes various types of knowledge more visible, such as colleagues' ideas about pedagogy and students' thinking, thereby enabling teachers to encounter new/different ideas, and to refine their knowledge (Lewis, Perry, \& Hurd, 2009, p. 286). In lesson study, observing the research lesson stimulates teachers to reflect on their teaching methods which result in a focus on student learning, and the teachers learn from their colleagues' classroom practices. In this way the learning processes activated by lesson study clearly resulted in improved teachers' professional development (Verhoef et al., 2015).

It was concluded that feedback and discussions about the observations in the lesson study improved the pre-service teachers' skills to use body language and tone in the teaching and learning processes. Ayantas (2019) reached similar conclusions as a result of his work with pre-service social studies teachers. Nami et al. (2015) carried out a study to investigate English teachers' perceptions of lesson study and stated that teachers 
appreciated this strategy as it promoted their knowledge of technology and their confidence in teaching with technology.

\section{The Sffect of the Lesson Plans Prepared in the Lesson Study Process on Students:}

In this study it was observed that the usage of lesson study had positive effects on students. Likewise, Gunawan (2017) made research to enhance students' activity in lecturing by implementing lesson study based instructional management and concluded that there was an improvement in terms of students' activeness in following the lecturing activity when lesson study based instructional management was implemented. Bozkurt and Yetkin-Özdemir (2016) investigated the feelings and opinions of a group of middle school mathematics teachers about lesson study and stated that lesson study displays quite important features such as promoting active engagement, enhancing teacher knowledge and increasing student motivation as a professional development model. Fadillah and his colleagues (2016) used lesson study and concluded that the learning outcomes of students in a treatment class is higher than the control class. The gain of students using lesson study is 0.79 and in the control class is 0.66 .

In this study the plans were student-centered, prepared to ensure the active participation of students and including group work. It was seen that this contributed to the fun of the lesson and effective learning, as well as increasing active participation, motivation, and cooperation among students. Researchers have shown that methods requiring students to work with each other increase student achievement (Nam \& Zellner, 2011; Ökmen, 2020; Shy-Jong, 2007) and motivation (Arısoy, 2011; Ökmen, 2020). It was observed that organizing activities that would require constructing dialogues contributed to the development of students' speaking skills and vocabulary knowledge. Activities such as role playing are particularly important for gaining communication skills such as speaking, listening, and watching (Maden, 2010: 516-517). There are studies in the literature that conclude that drama activities increase students' speaking skills (Aykac \& Cetinkaya, 2013; Kılıçarslan, 2014; Okmen, 2020). In addititon, it was concluded that group work is effective in students' learning and makes lessons enjoyable. There are studies in the literature showing that cooperative learning positively affects student achievements (Akbuga, 2009; Astra, Wahyuni, \& Nasbey, 2015; Ökmen, 2020) and attitudes about learning (Ökmen, 2020; Özdogan, 2008).

Based on the results obtained in the present research, the following suggestions were developed:

- The effects on students of lesson study methods that increase the professional development of pre-service teachers can be explored in detail.

- The Ministry of National Education should give importance to lesson study and ensure that this model reaches teachers.

- Pre-service teachers should begin their profession with training on the lesson study method in order to effectively implement this method in Turkey. For this purpose, attention should be paid to teaching such models in undergraduate courses.

- Activities should be prepared to keep students active, to practice, and to attract students' attention.

Group activities should be included in the teaching process. 


\section{References}

Akbuğa, S. (2009). Ilköğ retim 4. Sinıf matematik dersinde işbirlikli öğ renme ilkelerine göre yapılandırılmış grup etkinliklerinin öğrenci erişilerine ve tutumlarına etkisi [The effect of structured group activities according to cooperative learning principles on student access and attitudes in primary education 4th grade mathematics lesson]. (Unpublished master thesis), Dokuz Eylül University, İzmir.

Angelini, M.L., \& Álvarez, N. (2018). Spreading lesson study in pre-service teacher instruction", International Journal for Lesson and Learning Studies, 7(1), 2336. https:// doi.org/10.1108/IJLLS-03-2017-0016

Anney, V. N. (2014). Ensuring the quality of the findings of qualitative research: looking at trustwothiness criteria. Journal of Emerging Trends in Educational Research and Policy Studies, 5(2), 272-281.

Arısoy, B. (2011). Işbirlikli öğrenme yönteminin ötbb ve tot tekniklerinin 6. Sinıf öğrencilerinin matematik dersi "istatistik ve olasılı" konusunda akademik başarı, kalıcılık ve sosyal beceri düzeylerine etkisi [The effect of ebb and tot techniques of cooperative learning method on 6th grade students' academic achievement, retention and social skill levels in statistics and probability in mathematics.]. (Unpublished master thesis), Çukurova University, Adana.

Astra, I., Wahyuni, C., \& Nasbey, H. (2015). Improvement of learning process and learning outcomes in Physics learning by using collaborative learning model of group investigation at high school. Journal of Education and Practice, 6(11), 75-79.

Ates, G., \& Gunbayı, İ. (2017). Ortaokullarda İngilizce ogretmenlerinin yabancı dil ogretiminde karsılastıkları sorunlar [Problems faced by English teachers in foreign language teaching in secondary schools]. Egitim ve Ogretim Arastırmaları Dergisi, 6/2, 347-361.

Ayantaş, T. (2019). Sosyal bilgiler öğ retmen adaylarının meslek bilgisi yeterliklerinin geliştirilmesinde ders imecesi uygulamasi [Application of lesson study in the development of professional knowledge competencies of pre-service social studies teacher]. (Unpublished master thesis), Ankara University, Institute of Education Sciences, Ankara.

Aykac, M., \& Cetinkaya, G. (2013). Yaratıcı drama etkinliklerinin Turkçe öğretmen adaylarının konuşma becerilerine etkisi [The effect of creative drama activities on pre-seriveceTurkish teachers' speaking skills]. Electronic Turkish Studies, 8(9), $671-$ 682.

Baki, M., \& Arslan, S. (2015). Ders imecesinin (lesson study) sınıf öğretmeni adaylarının matematik dersini planlama bilgilerine etkisinin incelenmesi [Investigation of the effect of lesson study on classroom pre-service teachers' mathematics lesson planning knowledge]. Turk Bilgisayar ve Matematik Egitimi Dergisi, 6(2), 209-229.

Bilginer, S.(2010). Avrupa birliğ ine geçiş sürecinde ilköğ retim kurumlarında görev yapan yönetici ve öğretmenlerin yabancı dil öğ retimi ile ilgili tutum ve görüşlerinin incelenmesi [Examining the attitudes and opinions of administrators and teachers working in primary education institutions during the transition to the European Union on foreign language teaching]. (Unpublished master thesis), Maltepe University, Social Sciences Institute, İstanbul.

Bozkurt, E., \& Yetkin-Özdemir, I. E. (2016). Reflections from three mathematics teachers who conducted a Lesson Study practice. International Online Journal of Educational Sciences, 8(3), 272-289. 
Budak, A. (2012). Mathematics teachers' engaging in a Lesson Study at virtual settings. Educational Research and Reviews, 7(15), 338-343. http://dx.doi.org/10.5897/ERR12.018

Burroughs, E. A., \& Luebeck, J. L. (2010). Pre-service teachers in mathematics lesson study. The Mathematics Enthusiast, 7(2), 391-400.

Carrier, S. J. (2011). Implementing and integrating effective teaching strategies including features of lesson study in an elementary science methods course. The Teacher Educator, 46(2), 145-160. https://doi.org/10.1080/08878730.2011.552666

Cerbin, W., \& Kopp, B. (2006). Lesson study as a model for building pedagogical knowledge and improving teaching. International Journal of Teaching and Learning in Higher Education, 3(18), 250-257.

Costello, P. J. M. (2007). Action research. Continuum Books.

Demirel, O. (1993). Yabancı dil öğretimi ilkeler ynötemler teknikler [Foreign language teaching principles methods techniques]. Ankara: Usem Yayınları.

Dudley, P. (2014). Lesson Study: A handbook. http://lessonstudy.co.uk/wpcontent/uploads/2012/03/new-handbook-revisedMay 14.pdf

Engin, A. O. (2006). Yabancı dil (İngilizce) öğretiminde öğrenci başarısını etkileyen değişkenler [Variables affecting student achievement in foreign language (English) teaching]. Atatürk Üniversitesi Sosyal Bilimler Enstitüsü Dergisi, 8 (2), 287-310.

English Proficiency Index, (2018). http://www.ef.com.tr/epi/downloads/ , retrieved on 06/06/2019.

Fadillah, A., Dewi, N. P. L. C., Ridho, D., Majid, A. N., \& Prastiwi, M. N. B. (2017). The effect of application of contextual teaching and learning (CTL) model-based on lesson study with mind mapping media to assess student learning outcomes on chemistry on colloid systems. In International Journal of Science and Applied Science: Conference Series 1(2), 101-108.

Fernandez, M. L. (2010). Investigating how and what prospective teachers learn through microteaching lesson study. Teaching and Teacher Education, 26(2), 351-562. https://doi.org/10.1016/j.tate.2009.09.012

Freankel, J. R., \& Wallen, N. E. (2000). How to design and evaluate research in education. McGraw-Hill.

Glanz, J. (1999). A primer on action research for the school administrator. The Clearing House: A Journal of Educational Strategies, Issues and Ideas, 72(5), 301-304, https://doi.org/10.1080/00098659909599413

Groves, S. (2013). Implementing the Japanese problem solving lesson structure. Mathematics Education Research Groups of Australasia.

Gunawan, I. (2018). The implementation of lesson study based learning management and the effect toward students' activeness in lecturing. JPP (Jurnal Pendidikan dan Pembelajaran), 24(2), 51-63.

Hourigan, M., \& Leavy, A. M. (2019). Learning from teaching: pre-service primary teachers' perceived learning from engaging in formal Lesson Study. Irish Educational

Studies, 38(3), 283-308. https://doi.org/10.1080/03323315.2019.1613252

Hurd, J., \& Licciardo-Musso, L. (2005). Lesson Study: Teacher-led professional development in literacy instruction. Language Arts, 82(5), 388-395.

Johns, C. (2009). Becoming a reflective practitioner (3 ${ }^{\text {rd }}$ Ed.). Wiley-Blackwell. 
Kanauan, W., \& Inprasitha, N. (2014). Collaboration between inservice teachers and student intern in Thai lesson study. Procedia-Social and Behavioral Science Journal, 116, 28 32. https://doi.org/10.1016/j.sbspro.2014.01.163

Karabuğa, F. (2018). Practıcıng lesson study with efl teachers: a socıal constructıvist perspectıve for efl teacher professional development. (Unpublished Ph.D dissertation), Çukurova University, Social Sciences Institute, Adana.

Kılıç, A., Aydın, M., Ökmen, B., \& Sahin, S. (2019). Kuramdan uygulamaya ihtiyac belirleme [Determining the needs from theory to practice]. Pegem Akademi.

Kilıçarslan, R. (2014). Yabancı dil olarak türkçenin öğ retiminde drama yönteminin konuşma becerisine etkisi [The effect of drama method on speaking skills in teaching Turkish as a foreign language.]. (Unpublished Ph.D dissertation), On Sekiz Mart University, Institute of Education Sciences, Çanakkale.

Kotelawala, U. (2012). Lesson study in a methods course: Connecting teacher education to the field. The Teacher Educator, 47(1), 67-89. https://doi.org/10.1080/08878730.2012.633840

Kukey, H. (2018). Illköğ retim matematik öğ retmen adaylarının 5. Sinıf kesirler konusunda derse hazırlık süreçlerinin lesson study (ders imecesi) modeli kapsamında incelenmesi [Examination of pre-service mathematics teachers' preparatory processes for 5th grade fractions within the scope of the lesson study model]. (Unpublished master thesis), İnönü University, Institute of Education Sciences, Malatya.

Kvale, S. (2006). Dominance through interviews \& dialogues. Qualitative Inquiry, 12(3), 480500. https://doi.org/10.1177\%2F 1077800406286235

Lamb, P. (2015). Peer-learning between pre-service teachers: embracing Lesson Study. International Journal for Lesson and Learning Studies, 4(4), 343361. https://doi.org/10.1108/IJLLS-03-2015-0012

Lewis, C. C., Perry, R. R., \& Hurd, J. (2009). Improving mathematics instruction through lesson study: a theoretical model and North American case. Journal of Mathematics Teacher Education, 12, 285-304. https://doi.org/10.1007/s 10857-009-9102-7

Lewis, C., \& Tsuchida, I. (1998). A lesson is like a swiftly flowing river: How research lessons improve Japanese education. American Educator, 22(4), 12-17. https://doi.org/10.1177\%2F 136548029900200117

Miles, M. B., \& Huberman, A. M. (1994). Qualitative data analysis: an expanded sourcebook. (2 $2^{\text {nd }}$ ed.). Sage Publications.

Murata, A., \& Pothen, B. E. (2011). Lesson study in preservice elementary mathematics methods courses: connecting emergeing practice and understanding. In L, C,Hart, A, Alston and A, Murata(Eds.), Lesson study research and practice in mathematics education (pp. 103-116). Springer.

Murata, A., \& Takahashi, A. (2002). Vehicle to connect theory, research, and practice: How teacher thinking changes in district-level lesson study in japan. Paper Presented At The TwentyFourth Annual Meeting Of The North American Chapter Of The İnternational Group Of The Psychology Of Mathematics Education, Columbus, Ohio. https://files.eric.ed.gov/fulltext/ED471780.pdf

Nam, C. W., \& Zellner, R. D. (2011). The relative effects of positive interdependence and group processing on student achievement and attitude in online cooperative

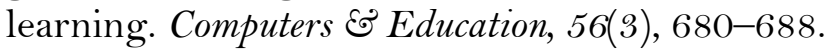
https://doi.org/10.1016/j.compedu.2010.10.010 
Nami, F., Marandi, S., \& Sotoudehnama, E. (2016). CALL teacher professional growth through lesson study practice: An investigation into EFL teachers' perceptions. Computer Assisted Language Learning, 29(4), 1-25.

https://doi.org/10.1080/09588221.2015.1016439

Ökmen, B. (2020). Developing the instructıonal process in layered flipped learning model. (Unpublished Ph.D dissertation), Düzce University, Social Sciences Institute, Düzce.

Ökmen, B., \& Kılıc, A. (2016). A research about the level of using language teaching methods and its effect on some variables: in Turkey, Universal Journal of Educational Research, 4(9),1994-2001. https://doi.org/10.13189/ujer.2016.040909

Ökmen, B., \& Kılıc, A. (2018). English course teaching practices. European Journal of English Language Teaching, 3(4),65-93. http://dx.doi.org/10.5281/zenodo.1312308

Özdemir, S. (1997). Her organizasyon hizmetiçi egitim yapmalıdır [Every organization should have in-service training]. Millî Egitim Dergisi, 133(1), 17-19.

Özdemir, T. Y., \& Yirci, R. (2015). A situational analysis of educational supervision in the Turkish educational system. Educational Process: International Journal, 4(1), 56-70. https://doi.org/10.12973/edupij.2015.412.5

Özdoğan, E. (2008). Issbirlikli öğ renme yönteminin ilköğretim 4. sinıf matematik öğ retiminde öğ renci tutum ve başarısına etkisi: bilgisayar destekli işbirlikli öğrenme ve küme destekli bireyselleştirme tekniğ $i$ [The effect of cooperative learning method on student attitude and achievement in primary school 4th grade mathematics teaching: computer-assisted cooperative learning and cluster-supported individualization technique]. (Unpublished master thesis), Ege University, İzmir.

Pektas, M. (2014). Effects of lesson study on science teacher candidates' teaching efficacies. Educational Research and Reviews, 9,(6), 164-172. https://doi.org/10.5897/ERR2013.1700

Puchner, L. D., \& Taylor, A. R. (2006). Lesson study, collaboration and teacher efficacy: Stories from two school-based math lesson study groups. Teaching and teacher education, 22(7), 922-934. https://doi.org/10.1016/j.tate.2006.04.011

Shy-Jong, J. (2007). A study of students construction of Science knowledge: Talk and writing in a collobrative group. Educational Research, 49(1), 65-81. https://doi.org/10.1080/00131880701200781

Sibbald, T. (2009). The relationship between lesson study and self-efficacy. School Science and Mathematics, 109(8), 450-460. https://doi.org/10.1111/j.19498594.2009.tb18292.x

Sims, L., \& Walsh D. (2009). Lesson Study with preservice teachers: Lessons from lessons. Teaching and Teacher Education, 25(5), 724-733. https://doi.org/10.1016/j.tate.2008.10.005

Slavin, R. E. (1994). Educational psychology: theory and practice (4th ed.). Allyn And Bacon.

Smith, R. R. (2008). Lesson study: Professional development for empowering teachers and improving classroom practice. (Unpublished Ph.D dissertation), Florida State University, Florida.

Solak, E. (2013). Finlandiya ve Turkiye'de ilkokul duzeyinde yabancı dil öğretimi [Foreign language teaching at primary level in Finland and Turkey]. Uluslararası Sosyal Araştırmalar Dergisi, 6/28.

Stigler, J. W., \& Hiebert, J. (1999). The teaching gap: best ıdeas from the world's teachers for improving education in the classroom. Summit Books. 
Stigler, J, W., \& Hiebert, J. (2016). Lesson study, improvement, and the importing of cultural routines. ZDM Mathematics Education, 48, 581-587.

https://doi.org/10.1007/s1 1858-016-0787-7

Suer, S., Demirkol, M., \& Oral, B. (2019). İlkokul İngilizce ogretmenlerinin ilkokul ingilizce dersi ogretim programı uygulamalarına iliskin yeterlik algılarının incelenmesi [Investigation of the proficiency perceptions of primary school English teachers regarding primary school English course curriculum practices]. Elektronik sosyal bilimler dergisi, $18(72)$, 1926-1941.

Takahashi, A., \& Yoshida, M. (2004). Ideas for establishing lesson-study communities. Teaching Children Mathematics, 10(9), 436-443. https://doi.org/10.5951/TCM.10.9.0436

Tasker, T. C. (2014). Exploring EFL teacher professional development through lesson study: An activity theoretical approach. (Unpublished Ph.D Dissertation), The Pennsylvania State University, The USA.

Verhoef, N. C., Coenders, F., Pieters, J. M., van Smaalen, D., \& Tall, D. O. (2015). Professional development through lesson study: teaching the derivative using GeoGebra. Professional development in education, 41(1), 109-126. https://doi.org/10.1080/19415257.2014.886285

Taylor, C., Wilkie, M., \& Baser, J. (2006). Doing action research: a guide for school support staff. Paul Chapman Publishing.

Yoshida, M. (2012). Mathematics lesson study in the United States: Current status and ideas for conducting high quality and effective lesson study. International Journal for Lesson and Learning Studies, 1(2), 140152. https://doi.org/10.1108/20468251211224181

Yoshida, M., \& Jackson, W., C. (2011). Ideas for developing mathematical pedagogical content knowledge through lesson study. In L, C, Hart., A. Alston ve A. Murata (Eds.), Lesson study research and practice in mathematics education (pp. 279-288). Springer.

Zepeda, S. J. (2012). Professional Development: What works (2nd edition). Routledge.

Zhang, N., Liu, Q., Zheng, X., Luo, L., \& Cheng, Y. (2021). Analysis of social interaction and behavior patterns in the process of online to offline lesson study: A case study of chemistry teaching design based on augmented reality. Asia Pacific Journal of Education. https://doi.org/10.1080/02188791.2020.1866493

Zhou, G., Xu, J., \& Martinovic, D. (2016). Developing pre-service teachers' capacity in teaching science with technology through microteaching lesson study approach. EURASIA Journal of Mathematics, Science and Technology Education, 13(1), 85-103. https://doi.org/10.12973/eurasia.2017.00605a

\section{About the Authors}

Burcu Ökmen graduated from Mehmet Akif Ersoy University English Language Teaching department in 2012. Between 2013 and 2015, she completed her master's degree in Duzce University, Curriculum and Instruction department. In 2020, she gained her Ph.D. degree at the same university and in the same field. She has been working as an English teacher in Duzce since 2012. Her academic interest areas are English teaching, program development, needs analyses, values education, student-centered education, instructional models. She has a book, 22 national and international articles, and 10 papers submitted to international meetings.

Abdurrahman Kılıç is a Professor at the Curriculum and Instruction department in the Education Faculty of Duzce University. He gained his Ph.D. degree in the field of 
Curriculum and Instruction at Hacettepe University in 2000. He became an associate professor in 2009 and a professor in 2014. His academic interest areas are program development, needs analyses, democracy, values education, student-centered education, instructional models. He has 3 books, 2 book chapters, over 60 national and international articles, and many papers presented at international meetings. 